\title{
OBSERVATIONS ON THE HISTORY OF THE 'GIRGLE OF WILLIS'
}

\author{
by
}

\section{ALFRED MEYER and RAYMOND HIERONS*}

THE term 'Circle of Willis' has been accepted for the characteristic arterial ramifications at the base of the brain, and widely used for about two hundred years. In truth, it is not a circle but an angular seven-sided structure termed 'heptagon' by Italian and some French writers. Moreover, Thomas Willis, who illustrated the 'circle' in his book Cerebri Anatome in I664, was not the first to describe this structure. During the subsequent centuries there were some who recognized this, as we shall see presently, but to the majority Willis's priority was and still is widely accepted without further discussion. Among the most commonly used modern textbooks of the history of medicine in the English language, only Mettler (1947) and Cole (1944) squarely deny Willis's priority; Garrison (1929), Castiglioni (1958) and Major (1954), however, do not question it. Singer (1957) does not bring his history of anatomy as far as the time of Willis, but he seems to accept the circle of Willis without reservation. In the case of Castiglioni, this omission is unexpected, as in the discovery of the circulation of the blood he appeared to divert to some degree, the glory from Harvey (whose pre-eminent part he frankly accepts) towards Harvey's Italian precursors Servetus, Columbus and Cesalpino.

\section{J. J. WEPFER ( $1620-95$ )}

Johann Jakob Wepfer of Schaffhausen in Switzerland has been quoted as the true discoverer of the 'Circle' before Thomas Willis. Dorley (1909), who described him as a 'renaissance student of apoplexy', praised Wepfer's

truly admirable and clear description of the vessels of the dura mater, of the vertebral arteries and of the internal carotid arteries with their branches and their terminal ramifications; [and he continues] It is interesting to note that in this connection he describes accurately the arterial circular anastomosis which came to bear the name of Willis.

More recently Nigst (1947) has devoted a monograph to Wepfer's anatomical work and particularly his investigation of the cerebral arteries. Wepfer, according to this author, was the first to illustrate the bend of the carotid artery and to give a good description of the course of the middle cerebral artery towards the lateral 'anfractus' with its large hiatus (i.e. the temporo-parietal lobes and the Sylvian fissure); and also of what we would call the callosal, posterior choroidal and superior cerebellar arteries. Nigst proves conclusively that Wepfer described the circle.

Grünthal (1957) also emphasized that Wepfer described the arterial circle

* From the Department of Neuropathology, Institute of Psychiatry, Maudsley Hospital and the Brook Hospital, London. 


\section{Alfred Meyer and Raymond Hierons}

six years before Willis. In order to show that this is correct, an abstract of the relevant passages of Wepfer will be given in translation. This abstract is taken from Wepfer's Observationes anatomicae ex cadaveribus eorum quos sustulit apoplexia (2nd edition 1675 , page 106 et seq.). Through the kindness of Dr. F. N. L. Poynter, Librarian of the Wellcome Historical Medical Library, we were able to ascertain that the text of this edition is in all essential detail of our subject, identical with the corresponding passages in the first edition of $165^{8}$ (pages 106 et seq.). The abbreviated and translated text runs as follows:

... As far as the carotid arteries are concerned, after emerging undivided from the bony canal, they continue winding and curving in a characteristic manner to the sides of the sella and of the pituitary gland, and there perforate the dura mater, and, though this is perforated for some distance, they still remain undivided, and are prominent a little above the dura. At this point, they are divided into an anterior and posterior branch, but not into an exterior and interior one, since no branch of these arteries in the human head is given off to the outside. The anterior branch, after passing the optic nerve, at once sends an artery to approach the notable and deep mass of convolutions and sulci (anfractus) of the cerebrum which is considerable in size. ... In order to see the larger and smaller branches issuing from it more accurately, the soft meninges which cover the outside of the convolutions in the whole surface of the brain and make it smooth, are to be removed either with finger or small scalpel. Thus, the artery and its offshoots may be excellently seen as a unit, as they proceed into the fissure in the depth of the convolutional mass and sulci, upwards towards the third sinus. They are for the most part free and not interwoven with the pia mater save through small twigs given off into the substance of the brain, and when these twigs are broken may be lifted and pulled out like fibres. ... The remaining part of the anterior arterial branch at the base of the brain proceeds towards the Crista Galli, and where the cerebrum is divided into two parts the right branch joins the left. In a number of cases, when a probe has been inserted, I have noticed both branches to be united. These, a little further on, are again separated, however, and proceed next to one another only as far as the Crista Galli to which they are attached. While they proceed anteriorly they give off several branches to the convolutions which face the fissure of the Cerebrum ... and turning back within the fissure proceed above the corpus callosum... . Some too clearly enter here into the lateral aspects of the cerebrum and into the depth of the corpus callosum... They also send on both sides tiny twigs to the falx....

The posterior branch of the carotid artery dispatches its first branch on both sides which enters the ventricles at the base of the brain ... advancing close to the choroid plexus beneath the border and supplying it with very fine twigs and capillary arteries. ...

After the posterior branch (of the carotid artery) has proceeded a little in its course, it is united with the vertebral artery which has again forked into two, and a continuous duct is established as can be seen if a probe is inserted....

As far as concerns the vertebral arteries, they emerge from the foramen proximum, the great orifice, through which the spinal medulla descends. They proceed to the sides of the medulla oblongata to which they supply a vast number of tiny branches which embrace them on all sides. When they have reached the place from which the sixth pair of nerves arise, the right and left branches are united, and they remain united over the whole extent of the medulla ...

Wepfer's description clearly shows that he knew in detail the anastomoses which make up the circle; the short quotations from his book also show the skill with which he traced all important ramifications (many for the first time) of the carotid and vertebral arteries. He gave no illustration of the arterial circle, but referred to one in the Syntagma Anatomicum of J. Vesling, saying that:

he does not explain in full everything which has been said and still remains to be said in ... dealing with these arteries. ... 


\section{Observations on the History of the 'Circle of Willis'}

It is curious that this important clue has not been taken up by Dorley, Nigst and Grünthal, although it reveals that Wepfer was not, nor indeed did he claim to be, the discoverer of the circulus arteriosus.

\section{johanN Vesling (Veslingus, Wesling, i 595-i 649)}

Johann Vesling first worked in Minden in Germany and later became professor of anatomy and surgery in Padua. The first edition of the Syntagma was published in Frankfurt in 1641 ; it does not contain illustrations and text relevant to our theme, these being included in the subsequent editions published in Padua in 1647 and 1651 . A later edition to which G. Blasius added commentaries appeared in Amsterdam in 1666. It was for almost fifty years a most popular anatomical textbook and had, according to von Töply (1903), I3 editions up to 1696 , including translations into German, Dutch and English. The English translation, by N. Culpeper, appeared in 1653 and was made from the 1647 Latin edition. Fig. I is taken from the English translation; both illustration and explanation are identical with those found in the 1647 (Latin) edition.

The illustration of the arterial circle is fairly accurate, though somewhat clumsy. It will be noted that a substantial union of the anterior branches of the carotid artery is missing though small vessels seem to be running between the two arteries in the depth (unless these are only background shading). Nor is there any mention of a junction of these arteries in the explanatory text. The posterior communicating artery appears as a direct continuation of the basal artery, after its redivision, without any indication of the existence of the posterior cerebral artery. What we now call the middle cerebral artery is seen to run towards the Sylvian fissure, apparently after removal of the temporal pole. In this point Vesling clearly anticipates Wepfer. The short branches given off mainly by the posterior communicating arteries around the 'Funnel' (stalk of the pituitary gland) correspond to the presumed site of the 'rete mirabile', a structure discovered by Herophilus and later described in detail by Galen as the place where the natural spirits ascending from the heart are converted into animal spirits. Galen, who used almost entirely brains of mammals for anatomical studies of the brain, believed that the rete was also present in the human brain. Medieval thought followed him in this until Berengario da Carpi (I 521,1523 ), Vesalius (1543) and, to some extent, Columbo (I 559), denied its occurrence in man. The letter $\mathbf{P}$ indicating the rete is also applied to nets of small arteries derived from the Sylvian artery and other vessels coursing on the under surface of the temporal lobe. It may be that these are a very inaccurate drawing of perforating branches usually confined to the (anterior and posterior) perforating spaces.

$$
\text { Givlio casserio (CASSERIUS, i 545-i6o5) }
$$

Tracing the history of the 'circle of Willis' even farther back, we encounter notable contributions by Giulio Gasserio and Gabriel Fallopius. Casserio, one 


\section{Alfred Meyer and Raymond Hierons}

of Harvey's teachers, was professor at Padua after Fabricius-i.e. from I604. His tabulae anatomicae were incorporated after his death in De humani corporis fabrica of Adrianus Spigelius (van der Spieghel, 1567-1625), whom Singer (1957) called the 'last of the great Paduans'. Spigelius also did not live to see the publication of his work which was eventually effected in 1627 in Venice by one of his disciples, Bucretius (alias Daniel Rindfleisch of Breslau), who added some less valuable imitations of Vesalius. Vesling proclaimed Casserio as one of the most diligent of Italian anatomists besides Vesalius and Fabricius, thus indicating that he was familiar with his work.

The neurological plates are contained in Book to of Spigelius's work. Fig. 2 is taken from plate Io. From this, it is obvious, that at least on the right, he has illustrated a complete 'circle'. There is an obvious discrepancy between the illustration and the explanatory text. While on the right side a posterior communicating artery is clearly visible, the text seems to correspond to the left side in the picture. As mentioned above, the text was not written by Casserio but by Bucretius (as the latter himself indicated in the title of the book).

Casserio's contribution to the 'eptagono scoperto piu tardi dal Willis' is acknowledged by Sterzi, his biographer (1909-10). Likewise Cole, in a biographical note, says of Casserio that 'he was the first to construct an accurate figure of the circle of Willis'.

\section{GABRIEL FALLOPIUS（FALLOPIO， I 523-62)}

Casserio's illustration is preceded by Fallopius's unillustrated but, as Mettler rightly emphasizes, painstaking description of the cerebral blood vessels contained in his Anatomical Obseroations ( $156 \mathrm{I}$ ). The relevant passages (pages $\left.13^{1-4}\right)$ in the second edition of $15^{62}$ are as follows:

(Arteria vertebralis) ... After entering the cranial cavity it joins with its opposite of the other side. The joint artery runs under the medial base of the brain until, in the region of the sella which contains the gland, it divides into two branches of which one creeps along the right side of the sella until the region of the 2nd pair of nerves; the same is done by its equivalent on the other side. There arrived, each divides into an infinite number of branches between the first and second pair of nerves, and is distributed and folded up within the soft cerebral membranes, with almost infinite branches which tend to form the plexus choroideus. . . .

(Arteria Karotis) It ascends, remaining unaltered in size, and arrives at the appropriate foramen in the os petrosum; through this it ascends into the cranial cavity near the sella, where it gives off (hidden below the dura membrane) an infinite number of branches in animals, forming the rete mirabile. In man, however, this rete is not marked, but only rather a shadow of itself and a vague image. These branches are given off by this artery so that it remains intact and is not reduced by its branches, as is usually the case with other arteries. After perforating the dura, it enters the cavity below the basis of the brain between the first and second pair of nerves, and divides there entirely into two branches of which the interior joins up with its interior equivalent (conjuge) of the other side, and forms one artery out of two. It is distributed and absorbed all around the beginning of the first pair of nerves and scattered in the soft membrane and the brain substance itself. The very exterior branch also produces similar arterioles of which a few join with arterioles of that (artery) which first (as was stated) proceeded along the base of the head beneath the cerebrum to this place. A few, however, are separately distributed within the soft meninges, where they supply the brain and form the choroid plexus. 


\section{Observations on the History of the 'Circle of Willis'}

This is the true story of the arteries, as far as they concern the Head which I have more often observed, and I have never been able to see any different behaviour. (Translation.)

We notice from these passages, that Fallopius clearly described the union and later division of the vertebral arteries, and the union of the interior rami of the carotid arteries (corresponding to our anterior cerebral arteries). $\mathrm{He}$ also described about two-thirds of a posterior communicating artery, but it had only indirect connection with the external branch of the carotid (corresponding to our middle cerebral artery), through a network of small arterioles between them. His description much resembles that in the explanatory legend of Casserio's illustration seventy years later. Bucretius when he wrote this legend must have leaned heavily on Fallopius's description.

\section{Rete mirabile}

None of the other great anatomists of the Renaissance period (among them Laurentius Phryesen (I518), Berengario da Carpi (I521, I523), Dryander (1536), Vesalius (1543), Estienne (I545), Jacobus Sylvius (1556), Columbus ( 1559 ), Eustachius (whose plates were drawn in $155^{2}$ but not published until I 7 I4) and Varolio (1573)) made any contribution to the problem of the circle which could compare in accuracy and completeness with that of Fallopius. Since they were all careful dissectors and observers, it is difficult to believe that this conspicuous structure at the base of the brain, striking even in brains of lower mammals, should have escaped their notice. They failed to recognize its significance, however, for several reasons: inability to distinguish arteries from veins, the bewildering number of ramifications, and, above all, preoccupation with the rete mirabile. Behind this rete there loomed the incredible authority of Galenic anatomy and physiology, magnified by its incorporation into scholastic concepts of the body-mind problem. One gleans some idea of the strong noumenal qualities associated with the rete if one reads the solemn description in medieval texts, for instance in the Anathomia of Mondino (written about 1316). The following is a translation of Mondino's relevant passages, quoted from Fonahn (1922):

And now lift the membranes from the bone . . . and you will find the rete mirabile; a most strongly interwoven tissue, with fine arteries miraculously duplicated and multiplicated; and alternatively interwoven with branches of the ascending arteriae apoplecticae (i.e. carotid). In this rete or in veins of this rete, is contained the vital spirit ascending from the heart to the brain, in order to become animal (spirit). For this reason the rete is composed of the smallest and most subtle veins or arteries, so that the spirit contained in them may be easily changed by the brain and be converted into the form of animal spirit: although it will acquire a greater perfection within the cerebral ventricles, like the blood in the ventricles of the heart. ...

Columbo's description of the basal ramifications, in some respects at least, comes nearest to that of Fallopius. He described correctly the union and subsequent redivision of the vertebral arteries, the branches of which, according to Lauth (1815), make contact with branches of the carotid arteries through 'un réseau admirable, plexus inconnu auparavant: c'est le même que nous appelons 


\section{Alfred Meyer and Raymond Hierons}

maintenant le circle artériel de Willis' (page 440). In this, however, Lauth was mistaken, for the rete mirabile of Columbo is the choroid plexus, and the link between the vertebral and corotid arteries is described by him not as a vessel in the approximate position of the posterior communicating artery but what would today be called the anterior and posterior choroidal arteries. Moreover, Columbo does not mention any union of the anterior branches of the carotid arteries.

There are indications that some of the other early anatomists have also seen more than the fanciful rete. Berengario, after giving the reasons for the nonexistence of this in man, adds 'And if this net is given, it is above the dura mater immediately below the medulla of the brain from whose smallest arteries therein is made a certain membrane continuous and similar to the pia mater in whose branches the vital spirit is subtilized and made into animal spirit. . . ' (translation by Lind and Roofe, 1959). Obviously, his physiological attention was more attracted by the small arteriolar ramifications in the pia mater and, possibly, the central ganglionic branches in the perforated spaces than the 'circle' as a whole. Vesalius likewise recorded the pial ramifications of what may have been the middle cerebral artery and the connections of the carotids with the choroid plexus through the anterior choroidal artery the calibre of which he greatly overrated. He also may have observed a vessel corresponding to the posterior communicating artery (Singer 1952). Jacobus Sylvius in his Isagogae (1556) remarks:

The artery which has reached the region of the choana (i.e. infundibulum and stalk) through the foramen magnium [sic!] sends off from there a small branch into the nose. Finally the total (of the artery) ends in two large branches which move forward, after a short progress join, but soon again divide. ... (Translation.)

This may refer to the union and later division of the anterior cerebral arteries. He was also aware of the forward course of the cervical (vertebral) arteries. Finally, Riolan (filius I649), one of the last defenders of the rete mirabile in man and as such severely criticized by Wepfer, concludes his statement on the rete as follows:

The rete mirabile described by Sylvius is that which is contained below the dura mater in the region of the base of the skull around the sella ..., where four arteries ascend and enter the brain: Two from behind penetrating through the IIth cranial foramen; two others, the socalled carotids, entering through the hiatus next to the optic nerves; and around the sella, these four arteries, connecting with each other, form that plexus which is indeed mirabilis or reticularis. (Translation.)

This sounds like a brief description of the arterial 'circle', rather than one of the rete.

\section{DISGUSSION}

From the account given in the preceding pages it appears that the distinction of having opened the history of the 'circle of Willis' should go to Fallopius. His was the first reasonably correct description of the basal arterial ramifications save for the posterior communicating artery which he thought was only indirectly connected with the internal carotid (and its branches) through a 


\section{Observations on the History of the 'Circle of Willis'}

network of small arteries. Casserio in his illustration corrected this mistake on one side, but left it as Fallopius had described it on the other side. The corresponding legend also followed more or less the Fallopian description. Twenty years later, Vesling illustrated a complete posterior communicating artery, but failed to demonstrate an unequivocal union of the anterior cerebral arteries. Wepfer's description in $165^{8}$ is superior to and more detailed than any of the preceding ones, but he did not give an illustration.

Thomas Willis, assisted by Richard Lower and Christopher Wren (who made the drawings), added little that was new to Wepfer's description, but he gave the first indisputably complete illustration of the 'circle' in both man and sheep (Figs. 3 and 4). Although he shares certain inaccuracies (for example, omission of the posterior cerebral arteries in both figures) with Vesling, the total pictorial presentation of the base of the brain and, in particular, of the relationship between blood vessels and cranial nerves, is superior to those of his predecessors. Willis contributed even more: being at heart a clinician he was not content with anatomical description, but tried to understand the functional and pathological significance. His explanation is so impressive that we wish to reproduce here the relevant passages, although they have been quoted by Sir Charles Symonds in his Harveian oration (1955):

But there is another reason far greater than this (i.e. mixing the blood) of these manifold ingraftings of the Vessels, to wit, that there may be a manifold way ...., for the blood about to go into divers Regions of the Brain ... so that if by chance one or two should be stopt, there might easily be found another passage instead of them: as for example, if the Carotides of one side should be obstructed, then the Vessels of the other side might provide for either Province.... Further, if both the Carotides should be stopped, the offices of each might be supplied through the Vertebrals.

In this connection, he remembered the case of a man dying from an intercurrent disease (ulcerated tumour of the mesentery), who at the beginning of his sickness, was tormented with

cruel pain of the Head towards the left side. [Post-mortem, an old thrombosis of the right Carotid was found]: . . . it seemed wonderful wherefore this sick person had not dyed before of an Apoplexy: which indeed he was so far from, that he enjoyed to the last moment of his life, the free excercise of his mind and animal function. . . . (Willis, ${ }^{*}$ 1684.)

This interpretation of anatomical findings in terms of physiology and pathology has an almost modern ring: it may well be one of the reasons why Willis's name became so closely linked with the circle. A further reason may have been the quality of his illustrations, in a book of sustained fame which Spatz (1959), in a happy phrase, has called the 'first monograph on the brain and nerves'.

It is puzzling to find no mention by Willis, when describing the basal arterial

* Willis's pre-occupation with (often speculative) physiological and clinical problems has led some (e.g. Foster (1901) and Mettler (1947)), to doubt his qualifications as an anatomist and scientist, and to believe that the main credit for the anatomical parts of Cerebri Anatome should go to his associates Richard Lower and Christopher Wren. As Symonds pointed out, there are insufficient reasons for this assumption which would be contradicted in any case by the high quality of Willis's later comparative anatomical investigations (1672). It is beyond the range of this paper to do full justice in this matter to both Willis and his critics. 


\section{GAPTIONS TO ILLUSTRATIONS}

Fig. I

From Vesling ( 1653 ). His legend states 'CC (indicates) the greater branch of the Artery Carotis, the interior being joined to the Vertebral Artery OO . . . OO (is) the common branch of the vertebral artery which being divided after its union with the Carotis artery CG makes up the Rete mirabile with it, about the seat of the wedg-like [sic!] bone. PPPP (are) small branches of the Arteries called the Rete mirabile'.

Fig. 2

From Casserio ( 1627 ) probably completed before 1616 . The translation of the text indicates that KK represents 'the larger branch of the Arteria Carotis interior. ... From this two others take their origin: the first, interior b.b. which later unites with the corresponding branch of the other side, near C. ... The branches of the cervical artery (called vertebrales by Spigelius) ... enter together (the cranial cavity) through the first large foramen of the occiput and soon unite, at $S$, beneath the beginning of the spinal medulla which is in it (the foramen magnum); thus, they run straight forward under the base of the brain in the midline. At the point where they reach the so called sella of the pituitary gland of the cuneiform bone, at about $T$, they divide into two branches, a right and a left (G.G.) which split into numerous small branches (h.h.) which join small branches of the internal carotid artery (f.f.) to form the choroid plexus'. (Translation.)

\section{Fig. 3}

From Willis, Practise of Physick (1684) showing the base of the human brain. Note the omission of the posterior cerebral (and superior cerebellar) arteries.

Fig. 4

From Willis (1684) - the base of a sheep's brain. The union of the anterior cerebral arteries is not quite as distinct as in the original of 1664 . The posterior cerebral is missing; instead Willis demonstrates (at TT) 'many Arteries (which) ascend to the Choroeidan infolding'. 


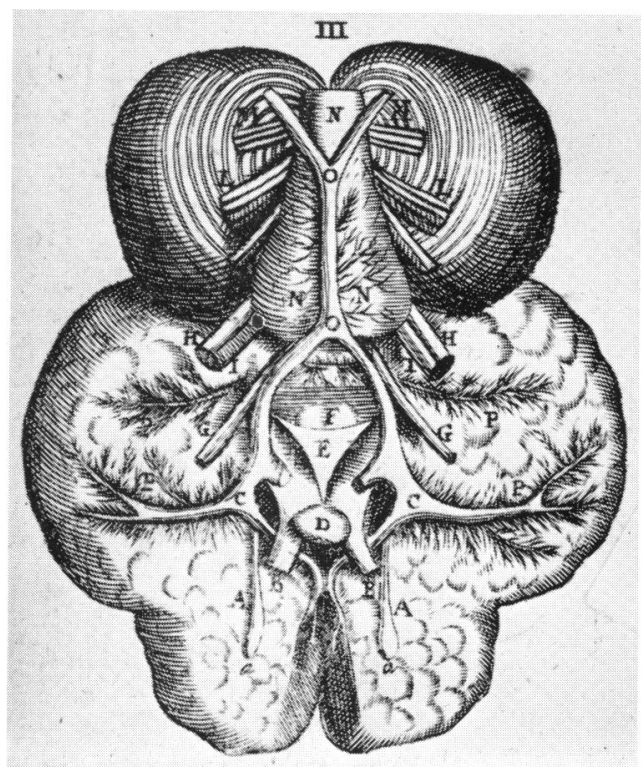

Fig. I

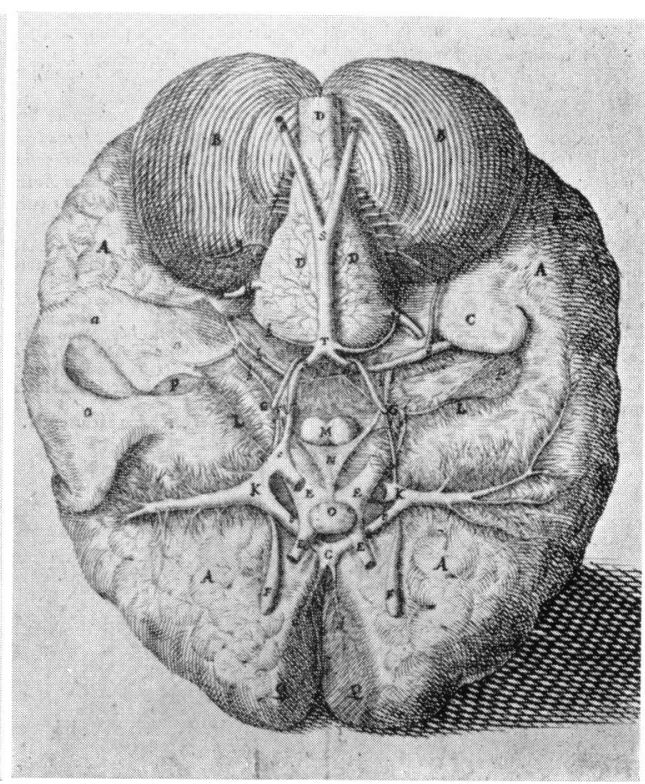

Fig. 2

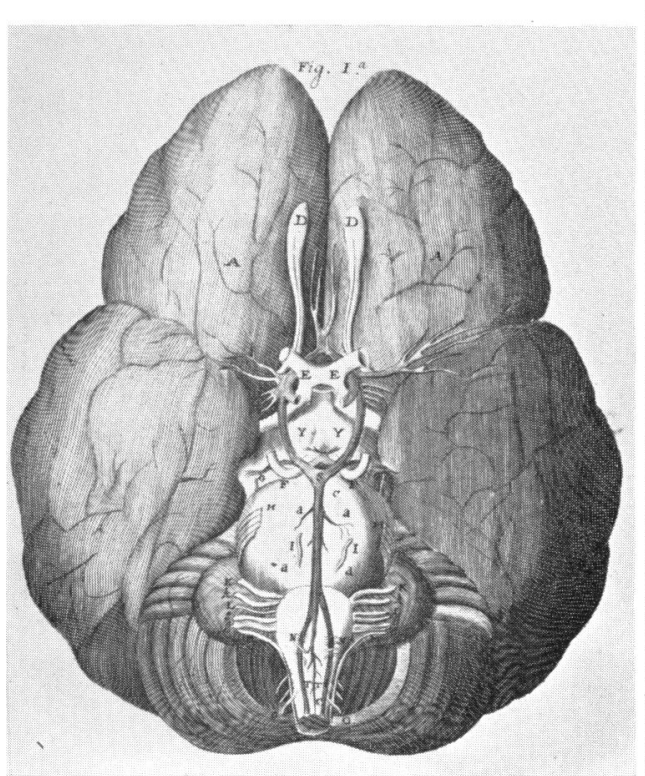

Fig. 3

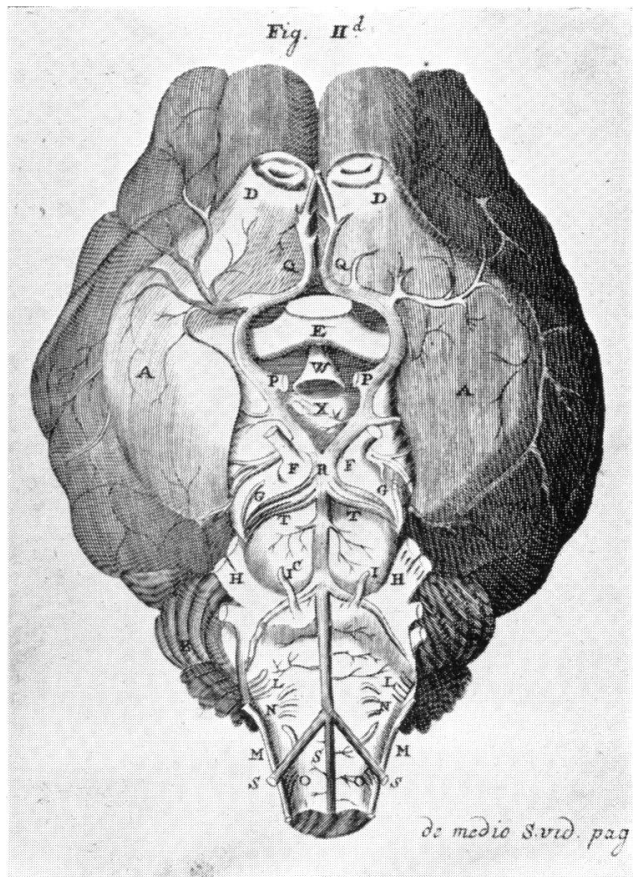

Fig. 4 


\section{Observations on the History of the 'Circle of Willis'}

ramifications, of the names of those who contributed to the problem previously. This applies to Wepfer in particular. Willis often referred to him in other contexts, using such adjectives as 'famous' or 'most learned', but omitting his name in relation to the circle. Such an omission is open to unfavourable interpretation, and it is only fair to emphasize, that Willis never claimed priority for the circle at any time. In order to understand this, it is necessary to recall, that at the time Willis's Cerebri Anatome appeared, the Syntagma Anatomicum of Vesling was available in Culpeper's translation and Willis and his reading public would surely be familiar with it. Likewise, Fallopius' and Wepfer's writings and Casserio's plates must have been well known to those interested in the anatomy of the brain. It would seem highly probable that Willis omitted these names as he knew that the question of priority was common knowledge.

In this connection, it is of interest that Willis's immediate successors in the field, among them Vieussens (I684), Ridley (I695), Leclerc and Manget (I699), Manget (I 7 I 7), Boerhaave (I 708) did not quote him, nor for that matter anybody else, as the discoverer of the arterial circle although most of them make appreciative or critical comments on Cerebri Anatome, and in particular the description of the cerebral arteries. Only Ridley briefly refers to Placentinus (i.e. Casserio) quoting a (wrong) page 'at the end of Spigelius'. He seems to be the first to have used the term 'communicant branches'. He criticizes 'Dr. Lower's and Dr. Willis's' illustration of the vertebral and basilar arteries, but his own description and picture of curved vertebral and wide basilar arteries seems to have been derived from an arteriosclerotic brain. One gains the impression that most of these writers were more or less aware of the historical evolution and none used the term 'circle'.

In 1774 , von Haller (Bibliotheca Anatomica, i, p. 476) speaks of the 'circulum qui dicitur Willisii', although, he says, all the latest information had been given not long before by Wepfer. In another place (page 290) he quotes Casserio having depicted 'circulum Willisii'. John Bell (1802) writes:

This anastomosis is the circle of Willis, too remarkable not to have been very long observed; it was drawn by Veslingus and by Casserius; it is but ill-represented by Bidloo and Cowper, it is not a circle, but is right lined, and of course angular. ...*

Von Toply's comprehensive history of anatomy (1903) does not supply any information except for a brief sentence on Wepfer whom he describes as 'a knowledgeable expert on the ramifications of the Carotid artery'. Nor do Laignel-Lavastine and Vie (1949) express any doubt on Willis's priority.

From these rather arbitrarily selected examples $\uparrow$ it seems that the true

* The last two works quoted by Bell were published after that of Willis.

+ We have consulted also other anatomical texts, published during the intervening centuries, including those of Lower (1669), Gibson (1682), Bidloo (1685), Cowper (1698), Dionis (1 703), Morgagni (1 719 , 1 769), Santorinus (1 724), Lieutaud (1 742), Sömmerring (1 778, 1800), Monro (1 783), Baillie (1 794), Quain and Wilson (1837), Knox (1853) and Gray (1858). All these authors, in describing the circle, either mention no names or simply refer to the 'circle of Willis'. Sömmerring ( 1800$)$, in addition to the terms 'circulus' and 'corona' speaks of the 'quadratum rotundoangulum'. It is interesting that Gray, in the first edition of his famous textbook, refers to the functional aspect (discussed above), saying: 'It is by this anastomosis that the cerebral circulation is equalized and provision made for effectually carrying it on if one or more of the branches are obliterated.' 


\section{Alfred Meyer and Raymond Hierons}

position concerning the priority of the 'circle' remained for a long time fairly widely known until - more recently - it fell into oblivion, with a few exceptions (usually hidden in specialized papers or treatises) to which attention has been drawn in the course of our exposition.

Like many other-and greater-discoveries, the correct recognition and description of the arterial ramifications at the base of the brain has had a long and gradual evolution; this review of it seems to confirm Long's (1928) warning against indulging in our curious and mistaken tendency to assign sudden paternity. ...'

\section{SU M M A R Y}

The discovery of the arterial 'circle' at the base of the brain has been a slow process from approximately 1560 onwards, and was largely due to the combined labours of Fallopius, Casserio, Vesling, Wepfer and Willis, each in turn making important contributions to its elaboration.

Wepfer, in 1658 , gave the first detailed and complete description. Thomas Willis (assisted by Richard Lower and Christopher Wren), in 1664 provided the first indisputably complete illustration. He also had the vision to grasp its function in health and disease, thus giving it life. In this restricted sense, the historical linkage of his name to the arterial circle may seem to have some justification.

Willis never claimed priority nor was it assigned to him by his contemporaries and immediate successors. It has been largely overlooked that at the time of the writing and the publication of Cerebri Anatome, Vesling's popular Syntagma had been available in English translation for several years.

\section{REFERENCES}

Bailife, M. (1794). The Goulstonian Lectures on the Anatomy and Physiology of the Nervous System (M.S. in the library of the Royal Society of Medicine, London).

BeLl, JoHN (1802). The Anatomy of the Human Body. 2. London.

Berengarius da Garpi, Jagopus (1521). Carpi Commentaria cum amplissimis additionibus super anatomia Mundini. Bologna.

Berengarius da Garpi, Jagopus (I530). Isagogae breves. First edition 1523. Strasbourg.

Be RE NG ARIUS DA GARPI, J A Co PUS (1959). A Short Introduction to Anatomy (Isagogae breves). (Translation into English by L. R. Lind. Anatomical notes by P. G. Roofe.) Chicago, Ill.

Bidloo, G. (1685). Anatomia humani corporis, centum et quinque Tabulis, per G. de Lairesse. Amsterdam.

BoerhaAve, H. (1 708). Institutiones Medicae. Leyden. (Translated into English as 'Academical lectures'. 1773, London.)

Casserius, Julius ( 1627 ). ' 78 Tabulae anatomicae' contained in Adrianus Spigelius, De humani corporis fabrica libri decem. Venice.

Castiglioni, Arturo (1958). A History of Medicine. Second enlarged English edition. New York and London.

Cole, F. J. (1944). A History of Comparative Anatomy. London. 


\section{Observations on the History of the 'Circle of Willis'}

Columbus, Realdus (1559). De Re Anatomica. Venice

CoWPER, William (1698). The Anatomy of Humane Bodies. Oxford.

Dionis, Peter (1 703). The Anatomy of Humane Bodies Improv'd According to the Circulation of the Blood and all the Modern Discoveries. (Translated from the 3 rd French edition.) London.

Dorley, J. E. (1909). Bull. 7. Hopk. Hosp., 20, I.

Dryander, Johannes (1536). Anatomia capitis humani. Marburg (quoted from Singer, 1952).

Estienne, Gharles (Stephanus Carolus) (1545). De dissectione partium corporis humani. Paris.

Eustachius, Bartholomaeus (I 7 I 4). Tabulae anatomicae, edited by J. M. Lancisi. Rome.

Fallopius, Gabriel (1562). Observationes anatomicae. First edition 1561. Venice.

Fon A H , A. (1922). Arabic and Latin Anatomical Terminology. Kristiania.

Foste R, M. (I9OI). Lectures on the History of Physiology during the I6th, I7th and I8th Centuries. Cambridge.

Garrison, H. Fielding (1929). An Introduction to the History of Medicine. 4th ed. Philadelphia and London.

Gibson, T. (1682). The Anatomy of Humane Bodies. London.

GrAY, H. (1858). Anatomy. London.

Grünthal, E. (1957). Biblioth. Psychiat. Neurol. roo, 94.

Haller, Albertus von (1774). Bibliotheca Anatomica. 1. Tiguri.

KNOX, RoBert (1853). A Manual of Human Anatomy. London.

Laignel-Lavastine, M. and Vie, J. (1949). 'Histoire de la Neurologie' in Histoire Générale de la Medicine (editor Laignel-Lavastine). III. Paris.

Laurentius Phryesen (1518). 'Spiegel der Artzney'. Strasbourg (quoted from Singer 1952).

Lauth, Thomas (1815). Histoire de L'Anatomie. Strasbourg.

Le Glerc, Daniel, and Mangetus, Jacobus (1699). Bibliotheca anatomica. II. First edition 1685 . Geneva.

Lieutaud, J. (1742). Essais Anatomiques. Paris.

Long, E. R. (1928). A History of Pathology. London.

Lower, Righard (1669). Tractatus de Corde. London.

Major, RAlPh H. (1954). A History of Medicine. 2 vols. Oxford.

Mangetus, J. (I 7I 7). Theatricum anatomicum. II. Geneva.

Mettie R, G. C. (1947). History of Medicine (edited by F. A. Mettler). Philadelphia and Toronto.

Mon ro, A. (Second) (1 783). Observations on the Nervous System. Edinburgh.

Morgagni, G. B. (I 7 I9). Adversaria Anatomica Omnia. Patavii.

Morg A G N I, G. B. (1 769). The Seats and Causes of Disease. (Translated from the Latin Text of 1761 .) London.

Mundinus (Mondino de Luzzi). (1487, but written in 1316.) Padova (quoted from Garrison).

Nigst, Hen ry (1947). Das Anatomische Werk Johann Jacob Wepfers. Aarau.

Quarn, J. and Wilson, W. J. E. (1837). The Vessels of the Human Body. London. Ridley, J. (1695). The Anatomy of the Brain. London.

Riolanus, J. filius (I649). Opera anatomica. Lutetiae Parisiorum.

RUySG H, F. (I 749). Tables of the Skeleton and Muscles of the Human Body. Contained in B. S. Albinus. London. 


\section{Alfred Meyer and Raymond Hierons}

SANTORINus, G. D. (1 724). Observationes anatomicae. Venice.

Singer, Gharles (1952). Vesalius on the Human Brain. London.

Singer, Gharles (1957). A Short History of Anatomy and Physiology from the Greeks to Harvey. New York and London.

Sömmerring, von S. T. (1 778). De Basi Encephali. Goettingae.

SömmerRING, von S. T. (1800). De corporis humani fabrica. V. Trajecti ad Moenum.

Spatz, H. (1959). In Ludwig Edinger (Schriften der Wissensch. Gesellsch. Universität Frankfurt a/M Naturw. Reihe I). Wiesbaden.

Ste RzI, G. Y. (1909). Nuovo Archivio Veneto (nuova serie). I 8, 208.

Sterzi, G. Y. (1910). Nuovo Archivio Veneto (nuova serie). I9, 25.

Sylvius (Dubors), Jacobus (1556). In Hippocratis et Galeni Physiologiae partem anatomicum Isagogae. Venice.

Sylvius (Dubois), Jacobus (1634). Opera medica. Geneva.

SyMONDs, C. P. (1955). Brit. med. F., r, 119.

Töply, von R. (1903). 'Geschichte der Anatomie' in Handbuch der Geschichte der Medizin (ed. M. Neubürger and J. Pagel). II. Jena.

VAROLIUS, G. (1573). De nervis opticis nonnulisque aliis praeter communem opinionem in humano capite observatis. Padua.

Vesalius, Andreas (I543). De humani corporis fabrica. Basileae.

Veslingus, J. (164r). Syntagma anatomicum. Frankfurt a/M.

-. (1647). Syntagma anatomicum. Padua.

-. (1666). Syntagma anatomicum (edit. and annotated by G. Blasius). Amsterdam.

-. (1653). Translated into English by N. Culpeper as The Anatomy of the Body of Man. London.

Vieussens, Raymond (1684). Neurographia Universalis. Lugduni.

WE P F E R, J.J. ( (1675). Observationes anatomicae ex cadaveribus eorum quos sustulit apoplexia. First edition 1658 . Schaffhusi.

Willis, Tномаs (i664). Cerebri Anatome. London.

-. (1672). De Anima brutorum. London.

-. (1684). Practice of Physick. London.

\section{ACKNOWLEDGMENTS}

We wish to express our thanks to the Wellcome Trust for an expenses grant; the Trustees of the British Museum for their permission to reproduce Fig. 2; to Professor Peter Daniel, Dr. F. N. L. Poynter of the Wellcome Historical Medical Library and Mr. P. Wade, Chief Librarian of the Royal Society of Medicine, for their help. 